\title{
Front Matter: Volume 11626
}

, "Front Matter: Volume 11626," Proc. SPIE 11626, Photonic Diagnosis, Monitoring, Prevention, and Treatment of Infections and Inflammatory Diseases 2021, 1162601 (23 April 2021); doi: 10.1117/12.2596811 


\title{
Photonic Diagnosis, Monitoring, Prevention, and Treatment of Infections and Inflammatory Diseases 2021
}

\author{
Tianhong Dai \\ Jürgen Popp \\ Mei X. Wu \\ Editors \\ 6-11 March 2021 \\ Online Only, United States \\ Sponsored and Published by \\ SPIE
}

Volume 11626 
The papers in this volume were part of the technical conference cited on the cover and title page. Papers were selected and subject to review by the editors and conference program committee. Some conference presentations may not be available for publication. Additional papers and presentation recordings may be available online in the SPIE Digital Library at SPIEDigitalLibrary.org.

The papers reflect the work and thoughts of the authors and are published herein as submitted. The publisher is not responsible for the validity of the information or for any outcomes resulting from reliance thereon.

Please use the following format to cite material from these proceedings:

Author(s), "Title of Paper," in Photonic Diagnosis, Monitoring, Prevention, and Treatment of Infections and Inflammatory Diseases 2021, edited by Tianhong Dai, Jürgen Popp, Mei X. Wu, Proc. of SPIE 11626, Seven-digit Article CID Number (DD/MM/YYYY); (DOI URL).

ISSN: 1605-7422

ISSN: 2410-9045 (electronic)

ISBN: 9781510640870

ISBN: 9781510640887 (electronic)

Published by

SPIE

P.O. Box 10, Bellingham, Washington 98227-0010 USA

Telephone +1 3606763290 (Pacific Time)

SPIE.org

Copyright @ 2021 Society of Photo-Optical Instrumentation Engineers (SPIE).

Copying of material in this book for internal or personal use, or for the internal or personal use of specific clients, beyond the fair use provisions granted by the U.S. Copyright Law is authorized by SPIE subject to payment of fees. To obtain permission to use and share articles in this volume, visit Copyright Clearance Center at copyright.com. Other copying for republication, resale, advertising or promotion, or any form of systematic or multiple reproduction of any material in this book is prohibited except with permission in writing from the publisher.

Printed in the United States of America by Curran Associates, Inc., under license from SPIE.

Publication of record for individual papers is online in the SPIE Digital Library.

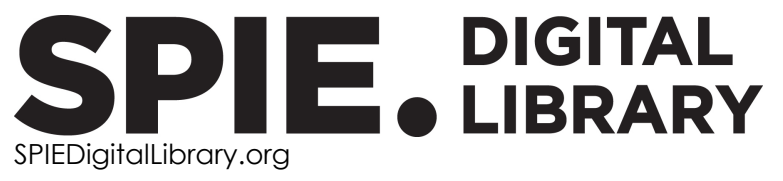

Paper Numbering: A unique citation identifier (CID) number is assigned to each article in the Proceedings of SPIE at the time of publication. Utilization of CIDs allows articles to be fully citable as soon as they are published online, and connects the same identifier to all online and print versions of the publication. SPIE uses a seven-digit CID article numbering system structured as follows:

- The first five digits correspond to the SPIE volume number.

- The last two digits indicate publication order within the volume using a Base 36 numbering system employing both numerals and letters. These two-number sets start with $00,01,02,03,04$, 05, 06, 07, 08, 09, 0A, OB ... 0Z, followed by 10-1Z, 20-2Z, etc. The CID Number appears on each page of the manuscript. 


\section{Contents}

OPTICS IN THE FIGHT AGAINST COVID-19 - I

1162606 Photobiomodulation and photodynamic therapy in COVID-19 management (Invited Paper) [11626-3]

OPTICS IN THE FIGHT AGAINST COVID-19 - II

1162609 Rapid detection of intact SARS-CoV-2 viral particles using silicon nanomembranes (Invited Paper) [11626-6]

OPTICS IN THE FIGHT AGAINST COVID-19 - III

11626 OC MHV-1 in vivo viral load reduction via antibody-conjugated photodynamic inactivation (Invited Paper) [1 1626-9]

ANTIMICROBIAL PHOTOTHERAPY - I

$116260 Q$ Antimicrobial photodynamic therapy for burn wound infection with $P$. aeruginosa in rats [11626-23]

POSTER SESSION

11626 OW Synergistic effect of laser and therapeutic ultrasound for fibromyalgia control: new development of protocols [11626-29]

$116260 \mathrm{X}$ Optical properties of porcine oral mucosa at application of iodine preparation based on glycerol [11626-30]

$116260 Z$ Analysis of Stokes shift spectra for distinguishing human prostate cancerous and normal tissues using machine learning methods [11626-32]

1162610 The application of MJF in the design of 3D printed nasal mid-turbinate swabs for the detection of COVID-19 [1 1626-33] 
Proc. of SPIE Vol. 11626 1162601-4

\section{Downloaded From: https://www.spiedigitallibrary.org/conference-proceedings-of-spie on 26 Apr 2023
Terms of Use: https://www.spiedigitallibrary.org/terms-of-use}

